\title{
Population structure, reproductive biology and feeding of Astyanax fasciatus (Cuvier, 1819) in an Upper Paraná River tributary, Misiones, Argentina
}

Estrutura populacional, biologia reprodutiva e alimentação de Astyanax fasciatus (Cuvier, 1819) em um tributário do alto Rio Paraná, Misiones, Argentina

Lourdes María Hirt, Patricia Raquel Araya and Silvia Alicia Flores

Laboratorio de Biología, Facultad de Ciencias Exactas, Químicas y Naturales - FCEQyN, Universidad Nacional de Misiones - UNaM, Felix de Azara, 1552, (3300) Misiones, Argentina e-mail: louma155@hotmail.com; araya@fceqyn.unam.edu.ar; syl_flor@hotmail.com

Abstract: Aim: The genus Astyanax is one of the richest in number of species and has one of the widest geographical distributions in Argentina, being possible to find in nine ichthyogeographic ecoregions. The aim of the present work was to analyze the population structure of Astyanax fasciatus in the Garupá Stream, Province of Misiones, Argentina, considering its distribution by size, standard length-total weight relationship and aspects of its reproductive and feeding biology; Methods: A total of eight experimental fishing campaigns were carried out between September 2002 and May 2004, in agreement with the seasons of the year, using a set of gillnets; Results: We captured a total of 386 individuals, $70 \%$ of which in the Middle Basin in autumn and winter. The following gonad stages were identified in both males and females: resting, maturing, mature and spawning. The highest gonadal activity corresponded to the autumn-winter period. The Middle Basin showed the highest capture of individuals in reproductive activity, thus reflecting the seasonality of spawning. The average fecundity was of 4000 oocytes, being $1100 \mu \mathrm{m}$ the largest oocyte diameter. The mean standard length of the total catch was $99.3 \mathrm{~mm}$ and females reached larger sizes than males $(\mathrm{P}<0.05)$. The standard length varied according to the seasons of the year. Both sexes presented an isometric growth $(b=3)$. Females presented the highest values of $\mathrm{K}$ in spring and summer, whereas males did so in spring. The K-GSI relationship reflected that the highest $\mathrm{K}$ values corresponded to the lowest GSI ones. We found that $A$. fasciatus feeds on a wide variety of foods of both plant and animal origin. The food items of plant origin presented the highest index of occurrence; Conclusions: The long spawning seasons and the recruitment along all four seasons of the year allow characterizing $A$. fasciatus as a foraging species that is very well adapted to the environment studied in this work.

Keywords: Astyanax fasciatus, population, reproduction, feeding, Garupa Stream.

Resumo: Objetivo: $O$ gênero Astyanax é um dos mais ricos em número de espécies e tem uma das maiores distribuições geográficas na Argentina, sendo possível encontrar em nove ecorregióes ictiogeográfica. O objetivo do presente trabalho foi analisar a estrutura populacional de Astyanax fasciatus no arroio Garupá, Província de Misiones, na Argentina, considerando a sua distribuição por tamanho, relação peso-padrão de comprimento total e aspectos de sua biologia reprodutiva e alimentação; Métodos: Foram realizadas oito operaçóes de pescaria sazonais, entre setembro de 2002 e maio de 2004, com uma bateria de redes de emalhar; Resultados: Foram capturados 386 indivíduos, $70 \%$ na Bacia Média no outono e inverno. Foram identificadas as seguintes etapas de maduração gonadal em ambos os sexos: repouso, maturação, maduro e desova. A maior atividade gonadal correspondeu ao período de outono-inverno. A Bacia do Médio apresentou a maior captura de indivíduos em atividade reprodutiva, refletindo a sazonalidade da desova. À fecundidade média foi de 4000 ovócitos, sendo $1100 \mu \mathrm{m}$ o maior diâmetro dos ovócitos. O comprimento padrão médio foi de $99,3 \mathrm{~mm}$ e fêmeas atingiram maiores tamanhos que os machos $(\mathrm{P}<0,05)$. $\mathrm{O}$ comprimento padrão variou de acordo com as estaçóes do ano. Ambos os sexos apresentaram crescimento isométrico $(b=3)$. As fêmeas registraram maiores valores de $\mathrm{K}$ em primavera e verão, enquanto os machos na primavera. A relação K-GSI mostrou que os maiores valores de $\mathrm{K}$ corresponderam aos menores de GSI. Observou-se que $A$. fasciatus alimenta-se de uma grande variedade de alimentos, tanto de origem vegetal como animal. Os alimentos de origem vegetal apresentaram o maior índice de ocorrência; Conclusóes: Os longos períodos de desova e de recrutamento ao longo das quatro estaçóes do ano permitem a caracterizaçáo de $A$. fasciatus como uma espécie forrageira que está muito bem adaptada ao ambiente estudado.

Palavras-chave: Astyanax fasciatus, população, reprodução, alimentação, Arroio Garupa. 


\section{Introduction}

The genus Astyanax is one of the richest in number of species, has one of the widest geographical distribution and includes several species of uncertain taxonomic location (Garutti and Britski, 1997). Several populations of Astyanax present scarce morphological, ecological and behavioral differentiation, which suggests that it is a group under speciation (Gurgel, 2004). Some of the species included in the genus are therefore under revision.

In the present work, we used the taxonomy of Reis et al. (2003), who refer to it as Astyanax fasciatus (Cuvier, 1819). Other authors, such as López et al. (2005), refer to it as Astyanax cf. fasciatus.

In Argentina, the genus Astyanax is distributed in nine ichthyogeographic ecoregions, mainly in the north and center of the country. López et al. (2002), Liotta (2005) and López et al. (2005) have reported 32 species, 14 of which are present in the province of Misiones, and seven of which are endemic (Vazzoler et al., 1997; Garutti and Britski, 2000). Since the species that integrate this genus constitute the food of carnivores such as the "dorado" Salminus brasiliensis (Cuvier, 1816), the "tararira" Hoplias malabaricus (Bloch, 1794), the "surubî" Sorubim lima (Bloch and Schneider, 1801), and Pseudoplatystoma coruscans, Spix and Agassiz, 1829, (Hahn et al., 1997), they constitute an important link in the food chain and maintenance of natural fish communities.

Astyanax fasciatus is an indicator of the Parano-Platense ichthyological region (López and Miquelarena, 2005), with a wide range of tolerance to abiotic factors such as conductivity, total dissolved solids, temperature and $\mathrm{pH}$ (Menni et al., 1996). In Brazil, this feature has led it to be considered a bioindicator of water contamination (Schulz and Martins, 2000).

Research related to the reproduction of this species in the Ceará Mirim River, the Arenal Reservoir in Costa Rica and the do Lobo Reservoir in Brazil has shown that $A$. fasciatus has complete spawning and that its highest reproductive activity takes place in October-November and DecemberJanuary (Mora-Jamett et al., 1996; Barbieri et al., 1996; Gurgel, 2004).

Findings on its feeding behavior indicate that $A$. fasciatus is an omnivorous species, with an insectivorous tendency (Nomura, 1975; Gutiérrez et al., 1983; Maia and MatusumuraTundisi, 1984; Silveira Vilella et al., 2002; Agostinho et al., 2003).
Data on its growth are available in the studies carried out by Nomura (1975) in the Mogi Guazú River (Brazil) and in those by Dei Tos et al. (2002) in the Corumbá Reservoir (Brazil).

A. fasciatus is one of the most captured species in the Garupá Stream (Flores et al., 2009). The mouth of this tributary of the Upper Paraná River is located upstream the city of Posadas, Province of Misiones, Argentina, in the zone of influence of the Yacyretá Dam, where an increase in the elevation (from 79 m.a.s.l to 83 m.a.s.l, in the PosadasEncarnación axis) is planned. This increase will produce substantial changes in the drainage regime of the Garupá Stream, the quality of its waters and its biodiversity. Its overflow will flood both the neighboring areas (where soils are used for different purposes) and the riverine vegetation, thus causing changes in the fish fauna.

The aim of the present work was to analyze the population structure of $A$. fasciatus in the Garupá Stream, by considering size distribution, the length-total weight relationship and aspects of its reproductive and feeding biology.

\section{Study Area}

The Garupá Stream is a $55 \mathrm{~km}$-long low order tributary of the Upper Paraná River. The drainage pattern of the basin is dendritic, with a marked slope and rocky bed, whose potamic stretch presents semipermanent marshlands and a developed floodplain.

The samples were collected in three sampling sites selected along the stream course (Figure 1): 1) a High Basin (27 $42^{\prime} 00^{\prime \prime} S$ and $\left.55^{\circ} 39^{\prime} 53.5^{\prime \prime} \mathrm{W}\right)$, with important marginal vegetation (gallery forest), which varies between 30 to $300 \mathrm{~m}$ in width and has a mean height of $8 \mathrm{~m}$, totally covering the riverbed in some parts, and which is continued with grasslands and fields for cattle breeding and agriculture. The riverbed here is rocky, with gravel and mud, the margins are pronounced ( $2 \mathrm{~m} \mathrm{high})$, and depth varies between 0.30 and $1 \mathrm{~m}$ during the dry seasons, and can increase significantly during the flooding that takes place in April and October as a consequence of pluvial precipitations; 2) a Middle Basin ( $27^{\circ} 33^{\prime} 27.5^{\prime \prime} S$ and $\left.55^{\circ} 41^{\prime} 16.5^{\prime \prime} \mathrm{W}\right)$, with an important development of the gallery forest, which covers the total width of the riverbed. The depth here increases and fluctuates between 1 and $2 \mathrm{~m}$, and the margins are less pronounced, a characteristic associated with overflows, which flood the floodplain when the stream grows; 3$)$ a Low Basin (27 $28^{\prime} 44.5^{\prime \prime} S$ and $\left.55^{\circ} 48^{\prime} 56.3^{\prime \prime} \mathrm{W}\right)$, associated with the mouth of the stream and 


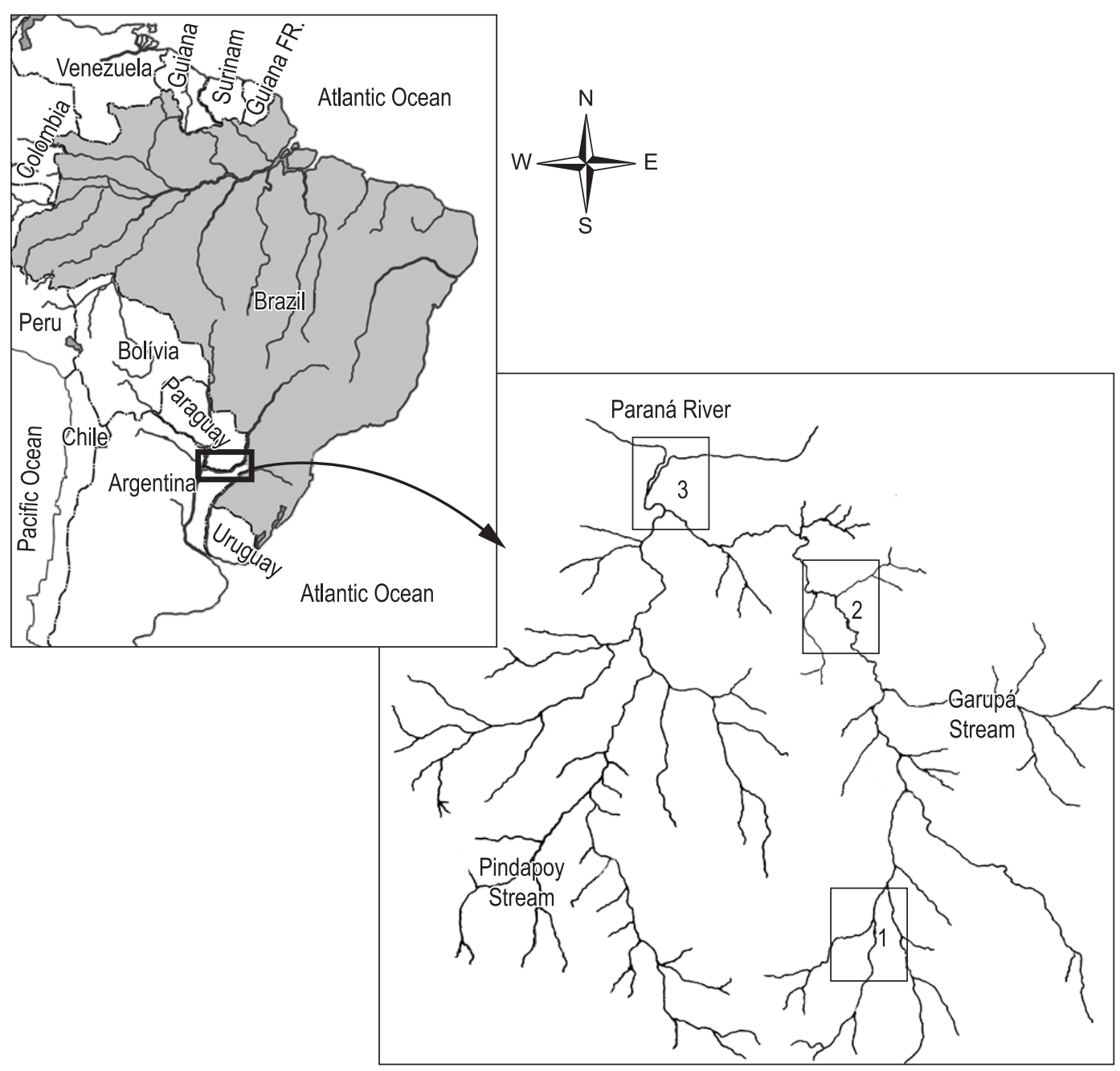

Figure 1. The study area with the sampling sites in Garupá Stream: 1) High Basin; 2) Middle Basin; and 3) Low Basin.

characterized by the widening and deepening of the stream, which reaches $50 \mathrm{~m}$ wide and $4 \mathrm{~m}$ deep. The decrease in the speed and the higher time of residence of the water allow the development of areas covered by aquatic plants of Eichornia crassipes Solms-Laub (1926).

\section{Material and Methods}

A total of eight experimental fishing campaigns were carried out between September 2002 and May 2004 , coinciding with the four seasons of the year of the Southern Hemisphere. A set of gillnets of 3 , 4, 6, 8, 10 and $12 \mathrm{~cm}$ mesh size between opposite knots was used. At each sampling site, the nets remained submerged for 24 hours and fish captured were extracted every 12 hours. The following data were recorded for each specimen: net or origin, total weight (TW) (g), standard length (SL) (mm), sex, macroscopic stage of gonads, and months of capture.

The digestive tracts were extracted and conserved in formol $4 \%$. The stomachs were dissected following the methodology proposed by Prej and Colomine (1981). The items present in the stomach content of each individual were identified under a stereoscopic microscope and an optical microscope to the best possible taxonomic resolution. We evaluated the relative importance of each item through the index of presence which is the rate between the number of stomach contents in which a certain item was present and the total number of stomach contents analyzed (multiplied by 100) (Hyslop, 1980). The samples analyzed corresponded to the sample sites located in the High and Middle Basin.

Foods were grouped in seven items according to the following description: 1) Plant material (PM): fragments of vascular plants: leaves, stems and roots, 
very partitioned plant material and organic debris;

2) Bacillariophyceae: centered and pennate diatoms;

3) Chlorophyceae: filamentous algae; 4) Fruit and seeds; 5) Insects: body parts: wings, legs, abdomen, larvae, empty cases of Trichoptera; 6) Fish: isolated fish scales; 7) Crustacea: Brachiopoda.

The macroscopic determination of the gonad stage was carried out considering features such as color, transparency, superficial vascularization, flaccidity, and, in the case of ovaries, size and position in the abdominal cavity and degree of visualization of the oocytes. We determined the following macroscopic stages of gonad maturation considered by Hirt and Flores (1999) for both sexes: resting, maturing, mature and spawned. The GSI was calculated in order to determine the stage of gonad maturation of females according to the following formula: GSI = GW*100/TW, where GW is gonad weight and TW is total weight in grams.

We also estimated the maximum oocyte diameter, using an ocular micrometer.

The distribution of gonad stages according to the seasons of the year was analyzed and absolute fecundity was calculated according to the gravimetric method by counting the number of mature oocytes from a $0.3 \mathrm{mg}$ sample (Araya et al., 2003).

In addition, we evaluated the distribution of the standard length classes ( $\mathrm{I}=10 \mathrm{~mm}$ ). Kolmogorov-Smirnov test were used to test for significant differences between standard lengths by sex (grouping variable) and one way ANOVAs were used to test for significant between standard lengths (dependent variable) by capture period (factors).

The weight of a fish varies directly with its length at any of its life stages (Ricker, 1975), according to the equation: TW $=a^{*} \mathrm{SL}^{b}$, where TW is total weight (g), SL is standard length (mm), and $a$ and $b$ are regression constants.

Based on this equation, we established a lengthweight relationship for males and females as well as for the total number of individuals.

The $a$ and $b$ constants were calculated by functional regression (Ricker, 1975), after the natural logarithmic transformation (ln): $\ln \mathrm{TW}=\ln a+b^{*} \ln S \mathrm{~L}$. T-test were performed to test whether the estimated $b$ values differed significantly from a value of $3: \mathrm{t}_{\mathrm{b}}=|b-3| / \mathrm{SE}_{\mathrm{b}}$, where $\mathrm{SE}$ is standard errors (Cinco, 1982).

The value of $b$ of the length-weight relationship was used to calculate the condition factor according to the formula: $\mathrm{K}=\mathrm{TW} / \mathrm{SL}^{b}$, and the individual values were calculated; the mean was obtained for each month and sex. The non-parametric KruskalWallis test and a post hoc Dunn's test were used to establish differences between the condition coefficient by season of the year and one-way ANOVAs by sex.

The control specimens are deposited at the Scientific Collection "Project Ichthyofauna of Misiones" (CIDET-School of Sciences, National University of Misiones, Argentina), under the catalog number 0078 .

\section{Results}

The total catches of $A$. fasciatus reached 386 individuals. The abundance showed both spatial and temporal variation. The highest number was found in the Middle Basin, mainly during autumn and winter (Table 1).

The following macroscopic stages of the gonads were recognized: resting, maturing, mature and spawning gonads. Resting ovaries are reduced in size, occupy approximately a third of the abdominal cavity and oocytes are not visible to the naked eye. At the beginning of maturation, ovaries occupy up to two thirds of the abdominal cavity, are more vascularized, and both small and opaque oocytes are visible to the naked eye. The mature stage is characterized by ovaries that reach their maximum size, thus occupying the whole cavity, and contain oocytes whose diameter can be over $500 \mu \mathrm{m}$. After spawning, the gonads become flaccid and smaller, although some oocytes can still be observed.

When considering the total number of individuals captured (386), most of the gonadal activity corresponded to autumn and winter. During winter, more than $50 \%$ of the females captured were mature and recorded the highest GSI (Figure 2).

In the High Basin, the percentage distribution of the gonad stages was uniform and the mature stage represented $27 \%$ of the total capture. Spawning females were recorded during summer and autumn and the mean seasonal GSI did not present significant variations (Figure 3a,b). In the High Basin, the highest capture was represented

Table 1. Abundance of $A$. fasciatus per sampling site and season in the Garupá Stream.

\begin{tabular}{lccc}
\hline & High basin & Middle basin & Low basin \\
\hline Summer & 25 & - & - \\
Autumn & 50 & 86 & - \\
Winter & 9 & 187 & 5 \\
Spring & 15 & 8 & - \\
\hline
\end{tabular}


by resting males, whereas in the Middle Basin it was represented by mature males. In the Middle Basin, $70 \%$ of the capture corresponded to the mature and maturing stages, the latter of which was predominant during autumn and winter (mean GSI $=6.4$ and $6.9 \%$ respectively). Autumn was the only season during which we were able to record spawning individuals (Figures $3 \mathrm{c}, \mathrm{d}$ ). The average fecundity of $A$. fasciatus was 4,000 oocytes, being

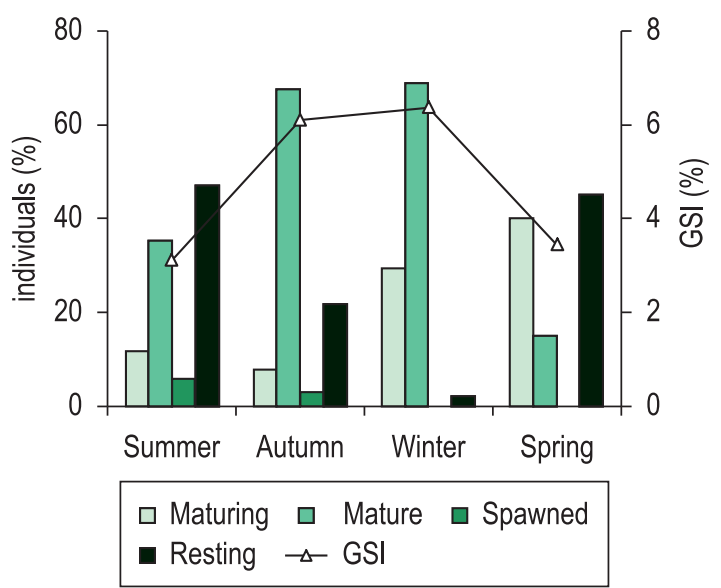

Figure 2. Variations in the gonad somatic index (GSI) of $A$. fasciatus and gonadal development stage for season year.
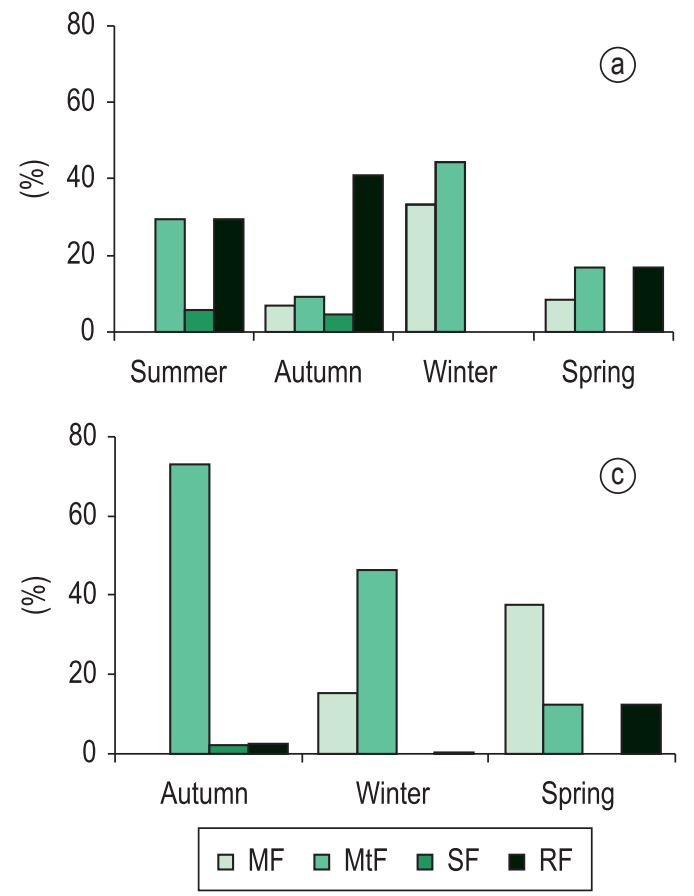

Figure 3. Percentage distribution of gonadal development stage of $A$. fasciatus. a,b) High Basin; c,d) Middle Basin. MF: Maturing Female, MtF: Mature Female, SF: Spawning Female, RF: Resting Female, MM: Maturing Male, MtM: Mature Male, RM: Resting Male.
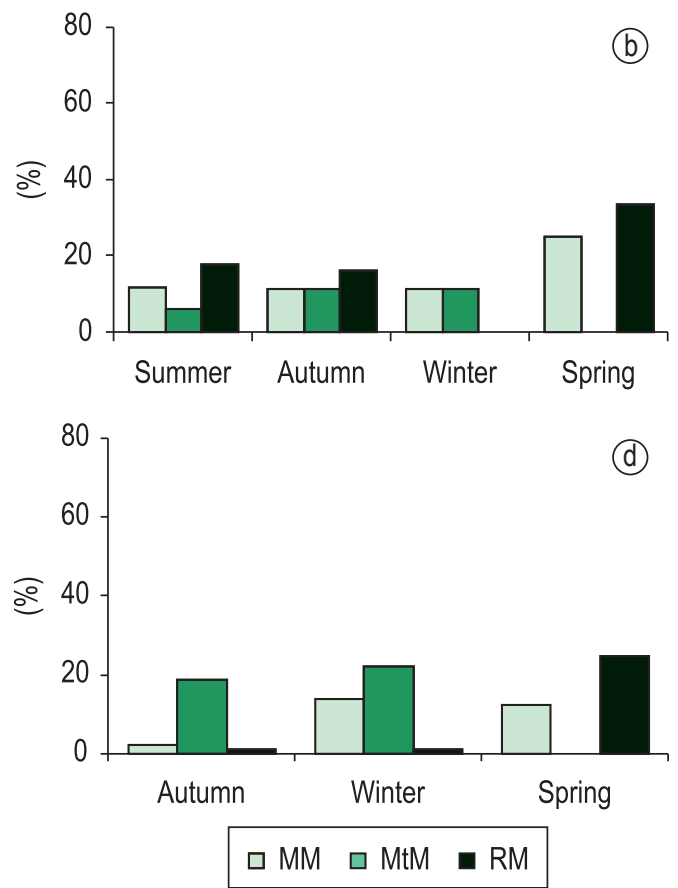

the maximum value 9,300 oocytes in an individual captured in the Middle Basin during winter. This individual was $115 \mathrm{~mm}$ long and weighed $37 \mathrm{~g}$. The average relative fecundity was 154 oocytes per gram of fish, being $510 \mu \mathrm{m}$ the diameter after which the oocyte was considered mature and $1100 \mu \mathrm{m}$ the largest diameter reached.

The average standard length of the total catch was $99.3 \mathrm{~mm}$, with a maximum of $135 \mathrm{~mm}$ and a minimum of $70 \mathrm{~mm}(\mathrm{n}=383, \mathrm{SD}=12.5)$. A statistically significant difference $(Z=2.683$; $\mathrm{P}<0.05$ ) was demonstrated (by two sample Kolmogorov Smirnov test) in the size for both sexes, being females longer than males (with the mode for females in the $120 \mathrm{~mm}$ class, and that for males in the $110 \mathrm{~mm}$ class) (Figure 4). The ANOVA also allowed us to confirm a significant difference $(\mathrm{F}=3.46 ; \mathrm{df}=3 ; \mathrm{P}<0.05)$ in the size of the individuals captured by season of the year, and the post hoc Scheffe's test allowed us to identify the difference between autumn and summer $(\mathrm{P}<0.05)$.

The estimated parameters in the length-weight regression equation discriminated by sex are presented in Table 2. For test t the parameter $b$ obtained did not evidence a significant difference $(\mathrm{P}<0.05)$ from the expected value $(b=3)$, for both sexes $\left(\mathrm{t}_{\text {females }}=1.51 ; \mathrm{df}=238 ; \mathrm{t}_{\text {males }}=1.60 \mathrm{df}=128\right)$. 
The results of the condition factor $K$ presented a variation along the study period. This variation was statistically significant by the Kruskal-Wallis test (Chi-Square: 15.7; df: 3 p: 0.001) and using the post hoc Dunn's test demonstrates that the difference was significant $(\mathrm{p}<0.05)$ only between autumn and winter.

When analyzing the results for $\mathrm{K}$ by sex, we observed that females presented the highest values in spring-summer, whereas males did so in spring; both sexes presented the lowest values in autumn (Figure 5). One-way ANOVA did not evidence a significant difference in this variation $(\mathrm{F}=2.616$; $\mathrm{df}=1 ; \mathrm{p}=0.107)$.

Table 2. Length-weight relationship of $A$. fasciatus.

\begin{tabular}{lccc}
\hline & M and F & $F$ & M \\
\hline $\mathrm{a}$ & $3 \times 10^{-5}$ & $3 \times 10^{-5}$ & $3 \times 10^{-5}$ \\
$\mathrm{~b}$ & 2.94 & 2.91 & 2.87 \\
$\mathrm{r}$ & 0.92 & 0.95 & 0.95 \\
$\mathrm{n}$ & 381 & 240 & 130 \\
\hline $\mathrm{Cl}$ & 2.81 & 2.79 & 2.71 \\
$(95 \%)$ & 3.06 & 3.02 & 3.03 \\
\hline
\end{tabular}

M: males, F: females, CI: 95\% confidence interval, $\mathrm{a}$ and $\mathrm{b}$ : regression parameters, $\mathrm{r}$ : Pearson correlation coefficient, $\mathrm{n}$ : number of individuals in the sample.
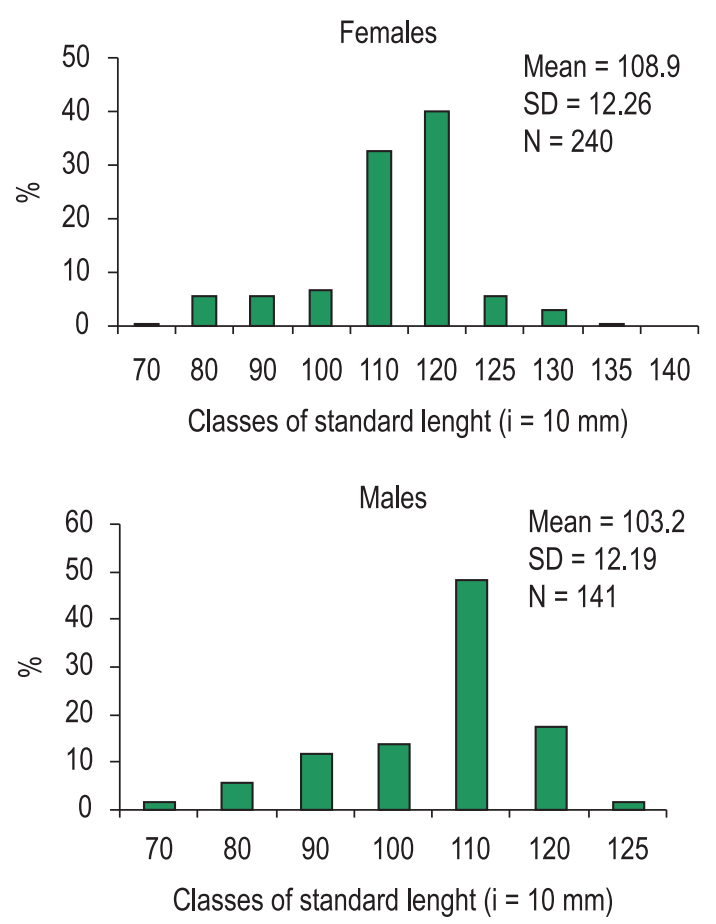

Figure 4. Size distribution for both sexes of A. fasciatus in the Garupa Stream.
The K-GSI relationship indicates that the highest values of GSI coincided with the lowest values of K (Figure 6). By means of Pearson's correlation we found that the association between the GSI and the mean condition coefficient by season of the year was negative (Pearson's correlation: -0.923; $\mathrm{N}: 4 ; \mathrm{p}<0.07)$.

A total of 56 stomach contents were examined: 40 of them were full whereas 16 of them were semifull. The standard lengths of the individuals analyzed were between 80 and $120 \mathrm{~mm}$, with a mean of $111 \mathrm{~mm}$.

The species presented a diet based mainly on higher plants, although material of animal origin was also present in the stomachs analyzed. The food items of plant origin presented the highest index of occurrence (Table 3), whereas filamentous algae and diatoms were also highly present. The food items of animal origin such as insects and crustaceans were less important.

\section{Discussion}

In the Garupá Stream, the relative abundance of species was adjusted to the characteristic pattern of multispecies communities in which one or

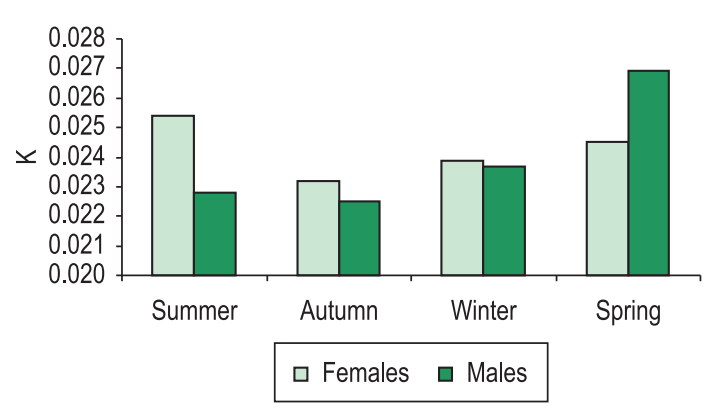

Figure 5. Variation of condition factor $(\mathrm{K})$ of $A$. fasciatus for both sexes and season year.

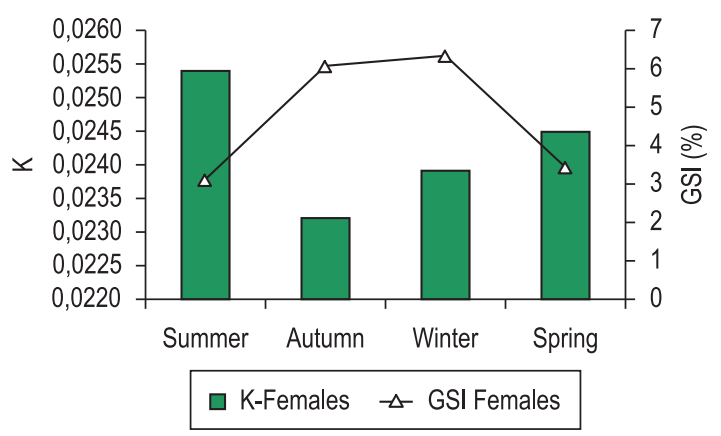

Figure 6. Variations in the gonad somatic index (GSI) and female condition factor $(\mathrm{K})$ of $A$. fasciatus in each season of the year. 
Table 3. Food items by $A$. fasciatus.

\begin{tabular}{llr}
\hline \multicolumn{1}{c}{ Food items } & $(\mathrm{IP})$ & $\mathrm{n}$ \\
\hline Plant material (PM) & 78 & 49 \\
Bacillariophyceae & 12.5 & 7 \\
Chlorophyceae & 23.5 & 13 \\
Fruit and seeds & 19.6 & 11 \\
Insects & 14.2 & 8 \\
Fish & 10.2 & 6 \\
Crustacea & 1.78 & 1 \\
\hline
\end{tabular}

IP: Index of occurrence, $\mathrm{n}$ : number stomachs in which the item was found.

two species are dominant and the other is rare. $A$. fasciatus was one of the most captured species in this environment. It presented spatial variations in its abundance, attributable to the physical, chemical and biological changes in the basin (Flores et al., 2009). The lowest capture in the Low Basin could be related to the potamic features of this sector and the presence of predator species that enter from the Paraná River looking for refuge or food (Flores et al., 2009).

Zaniboni-Filho and Schulz (2003) and Zaniboni-Filho and de Olivera Nuñer (2008) have reported that the mouth of streams are environments with favorable conditions for the growth of planktonic organisms and where young individuals of some migrating species, such as the "sábalo" Prochilodus scrofa (Valenciennes, 1836), the "boga" Leporinus obtusidens (Valenciennes, 1836) and the "dorado" S. brasiliensis, complete their life cycle. It can thus be inferred that biological factors such as the presence of predators could be the cause of the lower frequency of $A$. fasciatus in the Low Basin of the Garupá Stream. Also the small catch in this environment may be attributable to sampling error due to the presence of macrophytes which, according to the studies carried out by Casatti et al. (2003) and Dibble and Pelicice (2010), generate microhabitats that interfere in the distribution pattern of the small species.

Small species like $A$. fasciatus exhibit a short life cycle that is developed mainly in coastal habitats and present predominantly carnivorous or omnivorous feeding habits. According to Vazzoler and Menezes (1992) and Vazzoler (1996), feeding and reproductive features such as long periods of spawning, external fecundity, short-distance reproductive migrations and absence of parental care correspond to species considered opportunistic or r-strategists.

These characteristics, associated with its wide feeding habits, provide $A$. fasciatus with a great ecological flexibility. According to Agostinho et al. (2007), this flexibility allows its occurrence among the dominant species in $18 \%$ of the reservoirs studied in Brazilian hydrographic basins. On the other hand, Agostinho et al. (1995) report its occurrence in 11 reservoirs of the Upper Paraná River, whereas Roa (2005) do so in the Yacyretá Reservoir.

The long spawning periods and the capture along the four seasons of the year allow (Flores et al., 2009) characterizing $A$. fasciatus as a foraging species very well adapted to the environments of the Garupá Stream. A. fasciatus thus seems to play a key role in the trophic balance of this ecosystem.

Gurgel (2004) found that in the Ceará Mirim River, Brazil, females of this species are abundant from February to April, and that males are abundant from May to July, thus justifying the difference found in the gonad development of females. Due to the higher weight of their gonads, females could be more susceptible to being captured. According to the results by Flores et al. (2009), this factor could explain the highest captures recorded in autumn and winter in the Garupá Stream, which coincides with the higher averages of the gonadosomatic relation. Other factors such as the proportion of sexes or the availability of food could also explain this difference. According to Nikolski (1969), females predominate when food is abundant. In this sense, Wolter and Bischoff (2001) associated the reproductive season with the highest variations in abundance, biomass and distribution of the fish fauna of fluvial systems.

According to Vazzoler (1996), both the fecundity and the diameter of mature oocytes are very labile strategies, which present intraspecific variations as well as variations between successive reproductive periods. The values of fecundity recorded for $A$. fasciatus vary in relation with the environment studied, being, for instance, between 593 and 10,115 oocytes in the Mogi Guaçu River, and between 9,933 and 151,214 in the San Francisco basin, Brazil (Santos et al., 1996). These values are within the range of the results observed for A. fasciatus in other environments (Nomura, 1975; Barbieri and Barbieri, 1988).

The size of the oocytes does not depend on the size of the species; however, it is very much related to the reproductive behavior. According to a study carried out by Suzuki (1992) in 52 teleosts that inhabit the basin of the Upper Paraná River, the size of the oocytes varies between 427 and 4,789 $\mu \mathrm{m}$. In contrast, the results obtained in this work show that the $A$. fasciatus found in the Garupá Stream are 
among the species with lowest values of fecundity and oocyte diameter. According to Vazzoler, (1996), there is no direct relationship between fecundity and oocyte size. However, since it is a group with a similar reproductive behavior, the fecundity values are similar.

The Middle Basin of the Garupá Stream recorded the highest capture of individuals of A. fasciatus in reproduction and seasonal spawning. These results could be associated with more stable habitats, lower current speed and development of marginal vegetation, all of which contribute to providing important feeding resources and protection areas that may allow the development of the young. The situation in the High Basin is different: when the environment changes, the reproductive strategy seem to be to exhibit long reproductive periods along the four seasons of the year. Other factors that could influence the gonad maturation and spawning of other species are abiotic factors such as variations in the hydrometric level, rains, high temperatures and the photoperiod (Azevedo, 1972; Basile-Martins et al., 1975; Colares de Melo, 1989; Winemiller et al., 2000; Zeug and Winemiller, 2007). According to Pease et al. (2006), the flooding period and the low speed in flooding habitats are important factors for the reproduction and development of larvae.

The females of $A$. fasciatus extracted from the Garupá Stream were significantly larger than the males $(\mathrm{P}<0.05)$. A similar situation occurs in the Mogi Guazú River (Nomura, 1975) and in the Arenal Reservoir, Costa Rica (Mora-Jamet et al., 1997). However, some authors have found that males are larger than females, and have explained this by the fact that, during the first years of life, males grow faster than females (Agostinho et al., 1986).

The coefficients $a$ and $b$ of the length - weight may vary not only between species but within one same species, depending on weight, gonadal maturation and degree of stomach fullness, as well as sex, sexual maturity (Le Cren, 1950 apud Murphy and Willis, 1996; Rossi-Wongtschowski et al., 1982) and age (Rossi-Wongtschowski, 1977).

The parameter $b$ tends to assume values near to three, expressing the rate of increase. For values of $b$ close to three the increase is isometric (Gulland, 1985) well, the same rate of growth in different parts of the body. As shown in this work the values $b$ to $A$. fasciatus not differ significantly from three, so the weight increase follows the growth in length.
The regression coefficient and the constant regression present a remarkable inverse relation. Braga (1993) found an inverse variation between the regression coefficient and constant of regression for Paralonchurus brasillensis due to seasonal variation in the physiologic state of the fish, expressed by the condition factor. As the variation in the regression constant corresponds to the condition factor, that is, subject to seasonal oscillations, its variation can interfere in the variation of the regression coefficient. Braga (1997), suggests that the regression coefficient is not a good support indicator for characterization of different populations, because it can vary seasonally in the same population.

The condition factor of $A$. fasciatus presented variations along the study period and reflected the season and duration of the reproductive cycle (Narahara et al., 1985), as well as the nutritional state in relation with environmental factors (Le Cren, 1951; Gomes and Agostinho, 1997). Braga and Gennari (1990, 1991) observed that the condition factor and the fat accumulated accompany the rhythm of the reproductive process. These authors studied Moenkhausia intermedia Eigenmann, 1908, a species with characteristics similar to $A$. fasciatus and found that the mean values of $\mathrm{K}$ decrease with the increase in reproductive activity. They also concluded that during the reproductive period there is generally a decrease in the feeding activity, which contributes to a decrease in the values of $K$ during this stage. Lizama and Ambrósio (2002), who also worked with $M$. intermedia reached the same conclusions. The results of the present work evidence a similar situation since the lowest values of the condition factor were recorded in autumn and the highest ones in spring. This variation in the physiological index of the species seems to indicate the beginning of the reproductive period in the autumn and the recovery of the state during spring, as shown by the GSI values and the negative correlation between K and GSI.

By comparing the diet of fishes in three continents, Lowe-McConnel (1999) showed the importance of allochthonous material as the food of many species. Both aquatic and terrestrial species in different developmental stages, as well as organic matter and detritus because of their high content of microorganisms, play a significant role in fish feeding habits.

As expressed in the results section, the main feeding resource of the $A$. fasciatus of the Garupá Stream was constituted by plant material from higher plants in different degrees of partition, with 
a high index of occurrence. Although in the present study we could not establish the allochthonous or autochthonous origin of this material, we inferred that most of the plant material ingested by this species could be allochthonous because, as described above, the Garupá Stream has a great development of riverside vegetation both in its High and Middle Basins, considering the concept of fluvial continuum (Vannote et al., 1980). Several studies evidence that importance of the marginal vegetation in streams (Alvim and Peret, 2004; Sabino and Zuonan, 1998). However, further studies are necessary to confirm this hypothesis.

A. fasciatus was also found to have consumed Chlorophyceae and Bacillariophyceae algae, which are the classes of higher density and abundance of the phytoplankton community of the Garupá Stream, especially in the High and Middle Basins (Hirt et al., 2005). The $A$. fasciatus that inhabits the Garupá Stream has been defined as an omnivorous species with a tendency to be herbivorous. Other researchers have identified $A$. fasciatus as an omnivorous fish, with a tendency to be insectivorous (Esteves and Galetti, 1995; Meschiatti, 1995; Esteves, 1996) or zooplanktivorous (Barbosa and Matsumura-Tundisi, 1984). These observations are in agreement with the predominance of omnivorous species that combine the insectivorous and herbivorous forms reported by Araujo-Lima et al., (1995) for small streams of different South American basins.

\section{Acknowledgements}

We thank the Aquatic Subtropical Environment Biodiversity Project Members for their collaboration to obtain samples and the School of Sciences, National University of Misiones, Argentina, for the institutional support to carry out this research.

\section{References}

AGOSTINHO, AA., BARBIERI G., VERANI, JR. and AGOSTINHO, CS. 1986. Ciclo Reprodutivo y Primeira maturação de Rhinelepis áspera (Agassiz 1829), (Teleostei, Loricariidae) no rio Paranapanema. Revista UNIMAR, vol. 8, no. 1, p. 17-27.

AGOSTINHO, AA., GOMES, CL. and MAYER PELICICE, F. 2007. Ecologia e manejo de recursos pesqueiros em reservatórios do Brasil. Maringá: EdUEM. 501 p.

AgOstinho, AA., VAZZOLER, AEA, and THOMAZ, SM. 1995. The High River Paraná BasIn Limnological and Ichthyological Aspects. In TUNDISI, JG., BICUDO, CEM. and MATSUMURA-TUNDISI, T., eds. Limnology in
Brazil. Rio de Janeiro: Brazilian Academy of Science, Brazilian Limnological Society. p. 59-103.

AGOSTINHO, CS., HAHN, NS. and MARQUES, EE. 2003. Patterns of food resources use by two congeneric species of piranhas (Serrasalmus) on the upper Parana river floodplain. Brazilian Journal of Biology, vol. 63, no. 2, p. 177-182.

ALVIM, MCC. and PERET, AC. 2004. Food resources sustainning the fish fauna in a section of the upper São Francisco River in Três Marias, MG, Brazil. Brazilian Journal of Biology, vol. 64, no. 2, p. 195-202.

ARAUJO-LIMA, CA., AGOSTINHO, AA. and FABRÉ, NN. 1995. Trophic aspects of fish communities in Brazilian rivers and reservoir. In TUNDISI, JG., BICUDO, CEM. and MATSUMURA-TUNDISI, T., eds. Limnology in Brazil. Rio de Janeiro: Brazilian Academy of Science, Brazilian Limnological Society. p. 105-136.

ARAYA, P., HIRT, L. and FLORES, S. 2003. Biología reproductiva y crecimiento de Pimelodus clarias maculatus (Lac. 1803) (Pisces, Pimelodidae) en la zona de influencia del embalse Yacyretá. Ecología Austral, 13:83-95.

AZEVEDO, P. 1972. Principais peixes das aguas interiores de São Paulo, hábitos de vida. In COMISSÃO INTERESTADUAL DA BACIA PARANÁURUGUAI - CIBPU, ed. Poluição e piscicultura. São Paulo: Facultade de Saude Pública da Universidade de São Paulo, Instituto de Pesca. p. 109-112.

BARBIERI, G. and BARBIERI, MC. 1988. Curva de maduração, tamanho de primeira maturação gonadal e fecundidade de Astyanax bimaculatus Linnaeus, 1758 e Astyanax fasciatus Cuvier, 1819, da Represa do Lobo, estado de São Paulo (Osteichthyes, Characidae). Revista Ceres, vol. 35, no. 197, p. 64-77.

BARBIERI, G., HARTZ, SM. and VERANI, JR. 1996. O fator de condição e índice hepatossomático como indicadores de período de desova de Astyanax fasciatus da Represa do Lobo, estado de Sáo Paulo (Osteichthyes, Characidae). Iheringia Serie Zoology, vol. 81, p. 97-100.

BARBOSA, PMM. and MATSUMURA-TUNDISI, T. 1984. Consumption of zooplanktonic organisms by Astyanax fasciatus Cuvier, 1819 (Osteichthyes, Characidae) in Lobo (Broa) Reservoir, São Carlos, SP, Brazil. Hydrobiologia, vol. 113, p. 171-181.

BASILE-MARTINS, MA. , GODINHO, HM., FENERICH, NA. and BRAMLEY BARKER JM. 1975. Influencia de fatores abióticos sobre a maturação dos ovarios de Pimelodus maculatus Lac. 1803 (Pisces, Siluroidei). Boletim do Instituto de Pesca, vol. 4, no. 1, p. 1-28.

BRAGA FMS. and GENNARI FILHO, O. 1990. Contribuição para o conhecimento da reproduçáo de Moenkhausia intermedia (Characidae, 
Tetragonopterinae), na represa de Barra Bonita, rio Piracicaba, São Paulo. Naturalia, vol. 15, p. 171-188.

BRAGA, FMS. and GENNARI FILHO, O. 1991.

Estudos sobre a fecundidade, desova e mortalidade natural de Moenkhausia intermedia (Characidae, Tetragonopterinae), na represa de Barra Bonita, rio Piracicaba, São Paulo. Naturalia, vol. 16, p. 55-68.

BRAGA, FMS. 1993. Análise do fator de condição de Paralonchurus brasiliensis (Perciformes, Scianidae) Revista UNIMAR, vol. 15, no. 2, p. 99-115.

BRAGA, FMS. 1997. Analise da equação alométrica na relação peso-comprimento e o fator de condição em Plagioscion squamosissimus (Teleostei, Sciaenidae). Revista Brasileira de Biologia, vol. 57, no. 3, p. 417-425.

CASATTI, I., MENDES, H. and FERREIRA, K. 2003. Aquatic macrophytes as feeding site for small fishes in the Rosana Reservoir, Paranapanema River, southeastern Brazil. Brazilian Journal of Biology, vol. 63, no. 2, p. 213-222. http://dx.doi. org/10.1590/S1519-69842003000200006

CINCO, E. 1982. Length-weight relationship of fishes. In PAULY, D. and MINES, AN., eds. Small scale fisheries of San Miguel Bay. Philippines: Biology and Stock Assessment. p. 34-37. ICLARM Tech. Rep.

COLARES DE MELO, JS. 1989. Influência do fotoperiodo sobre a maturação ovariana de mandí Pimelodus maculatus Lacèpede, 1803. Boletim Técnico do Centro de Pesquisa e Treinamento em Aquicultura, vol. 2, p. 13-18.

DIBBLE, ED. and PELICICE, FM. 2010. Influence of aquatic plant-specific habitat on an assemblage of small neotropical floodplain fishes. Ecology of Freshwater Fish, vol. 19, p. 381-389. http://dx.doi. org/10.1111/j.1600-0633.2010.00420.x

DEI TOS, C. BARBIERI, G., AGOSTINHO, AA, GOMES, LC. and SUZUKI, HI. 2002. Ecology of Pimelodus maculatus (Siluriformes) In The Corumbá Reservoir, Brazil. Cybium, vol. 26, no. 4, p. 275-282.

ESTEVES, KE. and GALETTI, PM. 1995. Food partitioning among some characids of a small Brazilian floodplain lake from the Paraná River basin. Environmental Biology of Fishes, vol. 42, p. 375-389.

ESTEVES, KE. 1996. Feeding ecology of three Astyanax species (Characidae, Tetragonopterinae) from a floodplain lake of Mogi-Guaçú River, Paraná River Basin, Brazil. Environmental Biology of Fishes, vol. 46, p. 83-101.

FLORES, S., ARAYA, PR. and HIRT, LM. 2009. Fish diversity and community structure in a tributary stream of the Paraná River. Acta Limnologica Brasiliensia, vol. 21, no. 1, p. 57-66.

GARUTTI, V. and. BRITSKI, HA. 1997. Descrição de uma espécie nova de Astyanax (Teleostei, Characidae), com mancha umeral horizontalmente ovalada, da Bacia do Rio Guaporé, Amazônia. Papeis Avulsos de Zoologia, vol. 40, p. 217-229.

GARUTTI, V. and BRITSKI, HA. 2000. Descrição de uma espécie nova de Astyanax (Teleostei, Characidae) da bacia do Alto Rio Paraná e consideraçóes gerais sobre as demais espécies do gênero da bacia. Comunicaçðes Museu de Ciências e Tecnologia PUCRS Série Zoologia, vol. 13, p. 65-88.

GOMES, LC. and AGOSTINHO, AA. 1997. Influence of the flooding regime on the nutritional state and juvenile recruitment of the curimba, Prochilodus scrofa, Steindachner, in upper Paraná River, Brazil. Fisheries Management and Ecology, vol. 4, p. 263-274.

GULLAND, JA. 1985. Fish stock assessment: a manual of basic methods. Cichester: John Wiley \& Sons. 223 p. (FAO/WILEY Series on food and agriculture; vol. 1).

GURGEL, HCB. 2004. Estrutura populacional e época de reprodução de Astyanax fasciatus (Cuvier) (Characidae, Tetragonopterinae) do Rio Ceará Mirim, Poço Branco, Rio Grande do Norte, Brasil. Revista Brasileira de Zoologia, vol. 21, no.1, p. 131-135. http://dx.doi.org/10.1590/S010181752004000100022

GUTIERREZ, M., BARLA, MJ. and GIRAUDO, LM. 1983. Alimentación de la Población de Astyanax eigenmanniorum (Pisces, Characiformes) del lago San Roque. Revista Universidad Nacional de Río Cuarto, vol. 3, p. 131-141.

HAHN, NS., FUGI, R., VERA, L., RUSSO, M. and LOUREIRO, V. 1997. Dieta e atividade alimentar de peixes do Reservatorio de Segredo. In AGOSTINHO, AA. and GOMES, CL., eds. Reservatório de Segredo: bases ecológicas para o manejo. Maringá: EdUEM. p. 141-162

HIRT, LM., and FLORES, SA. 1999. Desarrollo ovocitario y tipo de desove de Acestrorhynchus pantaneiro (Cypriniformes, Characidae), en un tramo del río Alto Paraná, Argentina. Revista de Ictiología, vol. 7, no. especial, p. 67-74.

HIRT, LM., MEICHTRY, NR. , ARAYA, P., FLORES, S., PERMINGEAT, E., PESO, J., CARDOZO, A., RODRIGUEZ, M., RUIZ DIAZ BRITEZ, M. and VALLEJOS, R. 2005. Biodiversidad de ambientes acuáticos subtropicales. Misiones: FCEQyN; UNaM. 55 p. I Arroyos de Misiones. Programa Nacional de Incentivos a la Investigación.

HYSLOP, EJ. 1980. Stomach contents analysis, a review of methods and their application. Journal of Fish Biology, vol. 17, p. 411.429.

LE CREN, ED. 1951. The length-weight relationship and seasonal cycle in gonad weight and condition in the perch Perca Aluviatilis. Journal of Animal Ecology (Oxford), vol. 20, p. 201-219.

LIOTTA, J. 2005. Distribución Geográfica de los peces de Aguas Continentales de la República Argentina. Ganadería: Pesca y Alimentos de la República 
Argentina. 701 p. (Probiota Series Téchnica y Didáctica, no. 3).

LIZAMA, MDLAP and AMBRÓSIO, AM. 2002. Condition factor in nine species of fish of the Characidae family in the upper Paraná River floodplain, Brazil. Brazilian Journal of Biology, vol. 62, no. 1, p. 113-124.

LÓPEZ, HL., MORGAN, CC. and MONTENEGRO, MJ. 2002. Ichthyological ecoregions of Argentina. La Plata: Museo de La Plata. p. 1-68 (Probiota Series Téchnica y Didáctica, no. 1).

LÓPEZ, HL., MIQUELARENA AM., and PONTE GÓMEZ, J. 2005. Biodiversidad y Distribución de la Ictiofauna Mesopotámica. In ACEÑOLAZA, FG., eds. Temas de la Biodiversidad del Litoral Fluvial Argentino II. Universidad Nacional de Tucumán. p. 311-354. (INSUGEO Miscelánea, no. 14).

LÓPEZ, HL. and MIQUELARENA, AM. 2005. Biogeografía de los peces continentales de la Argentina. In LLORENTE BOUSQUETS, J. and MORRONE, JJ., eds. México Regionalización biogeográfica en Iberoamérica y tópicos afines. México: Universidad Nacional Autónoma de México. p. 509-550. Primeras Jornadas Biogeográficas de la Red Iberoamericana de Biogeografía y Entomología Sistemática.

LOWE-McCONNELL, RH., ed. 1999. Estúdios Ecológicos de Comunidades de Peixes Tropicais. São Paulo: EdUSP. 535p.

MAIA, PM. and MATSUMURA TUNDISI, T. 1984. Consumption of zooplanktonic organisms by Astyanax fasciatus Cuvier, 1819 (Osteichtyes, Characidae) in Lobo (Broa) Reservoir, Sáo Carlos, SP, Brazil. Hydrobiologia, vol. 113, p.171-181.

MENNI, RC., GOMEZ, SE. and LÓPEZ ARMENGOL, MF. 1996. Subtle relationships: freshwater fishes and water chemistry in southern South America. Hydrobiologia, vol. 328, p.173-197. http://dx.doi. org/10.1007/BF00017629

MESCHIATTI, AJ. 1995. Alimentação da comunidade de peixes de uma lagoa marginal do rio Mogi-Guaçu, SP. Acta Limnologica Brasiliensia, vol. 7, p. 115-137.

MORA-JAMET, M., CABRERA, J. and ALVARADO, W. 1997. Crecimiento y maduración sexual de Astyanax fasciatus (Pisces: Characidae) en el embalse arenal, Guanacaste, Costa Rica. Revista Biología Tropical, vol. 45, p. 855-859.

MURPHY, BR. and WILLIS, DW. 1996. Fisheries Techniques. Bethesda: American Fisheries Society. $732 \mathrm{p}$.

NARAHARA, MY., GODINHO, HM., FENERICHVERANI, N. and ROMAGOSA, E. 1985. Relação peso-comprimento e fator de condição de Rhamdia hilarii (Valenciennes, 1840) (Osteichthyes, Siluriformes, Pimelodidae). Boletim do Instituto de Pesca, vol. 12, no. 4, p. 13-22.
NIKOLSKI, GV. 1969. Theory of fish population dynamics. Edinburgh: Ed. Oliver \& Boyd. 323 p.

NOMURA, H. 1975. Comparison of the meristic characteristics of 3 species of fishes of the genus Astyanax Baird and Girard, 1854 (Osteichthyes, Characidae) in relation to environmental factors. Revista Brasileira de Biologia, vol. 35, p. 775-798.

PEASE AA., DAVIS, JJ., EDWARDS, MS. and TURNER, TF. 2006. Habitat and resource use by larval and juvenile fishes in an arid-land river (Rio Grande, New Mexico). Freshwater Biology, vol. 51, p. 475-486. http://dx.doi.org/10.1111/j.13652427.2005.01506.x

PREJ, A. and COLOMINE, G. 1981. Métodos para el estudio de los alimentos y las relaciones tróficas de los peces. Caracas: Universidad Central de Venezuela; Polonia: Universidad de Varsovia. 129 p.

REIS, RS., KULLANDER, O. and FERRARIS JUNIOR, CJ. 2003. Check list of the Freshwater Fishes of South and Central America. Porto Alegre: EdiPUCRS. 742 p.

RICKER, WW. 1975. Computation and interpretation of biological statistics of fish population. Bulletin of the Fisheries Research Board of Canada, vol. 191, p. 382 .

ROA, BH. 2005. Lista de especies de peces del tramo Ituzaingó-Iguazú. Revista de Ciencia y Tecnología, vol. 7, p. 73-79.

ROSSI-WONGTSCHOWSKI, C. 1977. Estudo das variacoes peso total/comprimento total en funcao do ciclo reproductivo e comportamente, de Sardinella brasiliensis (Steindachner,1879). Boletim do Instituto Oceanografico, vol. 26, p. 131-180.

ROSSI-WONGTSCHOWSKI, C., VAZZOLER, E. and BRAGA, F. 1982. Estudos sobre estrutura, ciclo de vida e comportamento de Sardinella brasiliensis (Steindachner,1879). Boletim do Instituto Oceanografico, vol. 3, no. 2, p. 57-76.

SABINO, J. and ZUANON, J. 1998. A stream fish assemblage in Central Amazonia: distribution, activity patterns and feeding behavior. Ichthyological Exploration of Freshwaters, vol. 8, p. 201-210.

SANTOS, GBL., BARROS, NV. and MENEZES, MU. 1996. Fecundity of the Astyanax bimaculatus (Reinhardt, 1874). (Teleostei, Characidae) from upper Rio São Francisco basin, Brazil. Arquivo Brasileiro de Medicina Veterinária e Zootecnia, vol. 48, no. 1, p. 101-108.

SCHULZ, UH. and MARTINS JUNIOR, H. 2000. Astyanax fasciatus as Bioindicator of Water Pollution of Rio Dos Sinos, RS, Brazil. Brazilian Journal of Biology, vol. 61, no. 4, p. 615-622.

SILVEIRA VILELLA, FF. BECKER, G. and. HARTZ, SM. 2002. Diet of Astyanax species (Teleostei, Characidae) in an Atlantic Forest River in Southern 
Brazil. Braz. Arquivo Brasileiro de Medicina Veterinária e Zootecnia, vol. 45, no. 2, p. 223-232.

SUZUKI, H. 1992. Variaçóes na morfologia ovariana e no desenvolvimento do folículo de peixes teleósteos da bacia do rio Paraná. Curitiba: Universidade Federal do Paraná. 140 p. [Dissertação Mestrado em Ciências Biológicas].

VANNOTE, RL, MINSHALL, K., CUMMINS, J., SEDELL, J. and CUSHING, C. 1980. The river continuum concept. Canadian Journal of Fisheries and Aquatic Sciences, vol. 37, no. 1, p. 130-7. http:// dx.doi.org/10.1139/f80-017

VAZZOLER, AEA., and MENEZES, NA. 1992. Síntese do conhecimento sobre o comportamento reprodutivo dos Characiformes da América do Sul (Teleostei, Ostariophysi). Revista Brasileira de Biologia, vol. 52, no. 4, p. 627-640.

VAZZOLER, AEA. 1996. Biologia da reprodução de peixes teleósteos: teoria e pratica. Maringá: EdUEM, Nupelia. 169 p.

VAZZOLER, A., AGOSTINHO, A. and HANN, N. 1997. A Planície de Inundação do Alto Paraná: Aspectos Físicos, Biológicos e Socioeconômicos. Maringá: EdUEM, Nupelia. 460 p.

WINEMILLER KO., TARIM, S., SHORMAN, ND. and COTNER JV. 2000. Fish assemblage structure in relation to environmental variation among Brazos River oxbow lakes. Transactions of the American Fisheries Society, vol. 129, p. 461-468.

WOLTER, C. and BISCHOFF, A. 2001. Seasonal changes of fish diversity in the main channel of large lowland River Oder. Regulated Rivers. Research \& Management, vol. 17, p. 595-608. http://dx.doi. org/10.1002/rrr.645

ZANIBONI-FILHO, E. and SHULZ, UH. 2003. Migratory Fishes of the Uruguay River. In CAROLSFELD, J., HARVEY, B., ROSS, C. and BAER, A., eds. Migratory Fishes of the South America: biology, Social importance and conservation status. Victoria: World Fisheries Trust, IDRC, World Bank. p. 157-194.

ZANIBONI-FILHO, E. and. DE OLIVERA NUNEER, AP. 2008. Reservatório de Itá: estudos ambientais, desenvolvimento de tecnologias de cultivo e conservação da ictiofauna. Florianópolis: Editorial da Universidade Federal De Santa Catarina. 319 p.

ZEUG, S. and WINEMILLER, K. 2007. Ecological correlates of fish reproductive activity in foodplain Rivers: a life- history- based approach. Canadian Journal of Fisheries and Aquatic Sciences, vol. 64, p. 1291-1301.

Received: 16 December 2010 Accepted: 14 July 2011 